\title{
STATISTICAL ANALYSIS OF AEROMYCOFLORA OF ACC JAMUL FACTORY AREA AND NON POLLUTED AREA IN JAMUL, BHILAI, DIST DURG, CHHATTISGARH, INDIA
}

Seema Verma and Arunima Karkun *

Gd Rungta College of Science and Technology, Kohka, Bhilai, Chhattisgarh

Received on: 02/03/16 Revised on: 26/04/16 Accepted on: 02/05/16

\author{
*Corresponding author \\ E-mail: seemaverma72@gmail.com
}

DOI: 10.7897/2277-4343.073115

\begin{abstract}
Fungi are an important microflora found in well diversified ecological conditions. In Chhattisgarh state, Jamul is situated in eastern region of Bhilai The floral and annual diversity of Jamul is a matter of Interest. Present paper deals with the fungal diversity in Jamul. For study of aeromycoflora, ten sterilized Petri plates containing PDA media were exposed 5 to $10 \mathrm{~min}$. in both ACC and non polluted area of Jamul. These exposed Petri plates brought into the laboratory and incubated at $28 \pm 1^{\circ} \mathrm{C}$ for incubation period.. During the period of investigation, overall 68 fungal species (1371 fungal colonies) belonging to 30 genera of fungi were observed in ACC factory area and 77 fungal species (1687) fungal colonies) belonging to 34 genera of fungi were observed in non polluted environment of Jamul. Statistical analysis viz Test and Two Way ANOVA has been performed for statistical analysis
\end{abstract}

Keywords: Aeromycoflora, Statistical analysis and Anova test

\section{INTRODUCTION}

Aerobiology is a scientific and multi disciplinary approach focused on the transport of organisms and biologically significant materials. Aerobiology, not only deals with different kinds of organisms however additionally with their merchandise together with, spores and cells of bacteria, Actinomycetes, fungi and associated metabolites, pollen grains of upper plants, mites, insects, their fragments and fecal pallets, macromolecules discharged from the plants and animal cells etc. Impact of these on organisms includes infection, hypersensitivity reaction and toxicosis in man, animals and in plants. Lacey ${ }^{1}$, declared that 'Aerobiology is therefore a discipline in itself however, one that attracts and is used by the researchers in many fields. Every day, we are exposed to such airborne particles, like fungi, pollen, bacteria, and harmful particles, such as asbestos fibers and noxious chemicals. Air borne particles cause biodeterioration, allergy and disease in humans, animals and plants. Airborne conidium frames the major part of a range of airborne particles that may also include hyphae fragment, pollen grains and small particulate material (Bioaerosole). For the eco- management to achieve success it might be necessary to own a radical data concerning the sort and range of microorganisms within the atmosphere of an area which helps in formulating a correct ecomanagement strategy for the place.

Fungi are remarkable for their antiquity, diversity, ubiquitous distribution and longevity ${ }^{2}$. Therefore, a study on air borne fungi has been conducted in ACC cement factory Jamul Industrial town of Bhilai which is one of the biggest industrial towns in the country and their statistical analysis has been done. Our study area is ACC Jamul factory area and non polluted area away from the factory, throughout the year both places are very crowded due to industry and village. During study we did comparative analysis of ACC Jamul factory area and non polluted area away from the factory.

\section{MATERIALS AND METHODS}

\section{Sample collecting area}

Jamul is situated in the eastern region of Durg District Chhattisgarh and situated in $21.25^{\circ} \mathrm{N}$ North latitude and 81.4 East longitudes above 298.60 meter the sea levels. ACC (Associated Cement Companies) Jamul factory area is the main environment where air is very polluted from cement dust and soot. The climatic condition of Jamul city is divided by rainy seasons (July-October) winter (November-February) and summer season (March-June).

\section{SURVEY OF AEROMYCOFLORA}

For study of aeromycoflora, ten sterilized Petri plates containing PDA media were exposed 5 to $10 \mathrm{~min}$. in ACC and non polluted area of Jamul. These exposed Petri plates brought into the laboratory and incubated at $28 \pm 1^{\circ} \mathrm{C}$ for incubation period. At the end of incubation period fungal colonies were counted, isolated and identified with the help of available literature (Barnett 1969) Ellis (1988) and finally identified by the authentic authority. Targeted fungi were got identified by authentic centre TFRI (Tropical Forest Research Institute) Jabalpur. (M.P)

Potato dextrose agar media;

Dextrose - $20 \mathrm{gm}$

Potato - $250 \mathrm{gm}$

Agar - 15 gm

Distilled water - $1000 \mathrm{ml}$

\section{Seasonal Variation}

i. Seasonal variation of the aeromycoflora over Jamul Cement factory area and non polluted area of Jamul.

ii. Monthly variation of the aeromycoflora over the Jamul factory area and non polluted area of Jamul. 


\section{ECOLOGICAL STUDIES}

For ecological studies, at the end of the incubation period of the indoor and outdoor Aeromycoflora, percentage frequency and percentage contribution of fungal flora were calculated. These formulas were assessed by Jadhav and Tiwari ${ }^{3}$ and Shrivastava et $a l,{ }^{4}$. Similar work were done by karkun and coworkers, ${ }^{5}$

$\%$ Frequency $=$ Number of observations (plates) in which a species appeared / Total no. of Observations) X 10

$\%$ Contribution $=$ Total number of colonies of a species in all the observations taken together / Total No. of colonies in all the species X 100

\section{Meteorological Data}

The following meteorological data were recorded from ACC administrative office of the Jamul factory:

- Temperature

- Relative humidity and

- Rainfall

\section{FOR SOURCES MYCOFLORA ISOLATION}

Fungal spores, ubiquitous in nature are adapted to all kinds of environment. Fungi originate from different sources i.e. plants, water and soil and area become contaminated. They are transported through air current, from one place to another place. Plants, soil and water are the major sources of Aeromycoflora. In present study air samples were collected for isolation of mycoflora.

Statistical analysis: t Test and Two Way Anova has been performed for statistical analysis.

\section{RESULTS AND DISCUSSION}

\section{Mycobial Survey}

The present investigation deals with the ACC Jamul factory area and non polluted area of Jamul by using gravity petriplate (containing PDA medium) method from July 2013 to June 2014. During the period of investigation, overall 68 fungal species (1371 fungal colonies) belonging to 30 genera of fungi were observed in ACC factory area and 77 fungal species (1687) fungal colonies) belonging to 34 genera of fungi were observed in non polluted environment of Jamul.

Table 1: Comparative study of fungal diversity of ACC Jamul factory and Non Polluted area

\begin{tabular}{|c|c|c|}
\hline & ACC Jamul factory area & Non Polluted area \\
\hline Total species & 68 & 77 \\
\hline \multicolumn{3}{|l|}{ Rainy season } \\
\hline Zygomycotina & 4 genera( 6 species) (17 colonies) & 4 genera ( 7 species) ( 25 colonies $)$ \\
\hline Basidiomycotina & - & - \\
\hline Ascomycotina & 1 genus ( 1 species) ( 5 colonies) & 3 genera ( 3 species) ( 15 colonies) \\
\hline Anamorphic fungi & 9 genera (34 species) (234 colonies) & 8 genera (37 species) (247 colonies) \\
\hline Mycelia sterilia & 1 genus (2species) (29 colonies) & 1 genus ( 2 species) (34 colonies) \\
\hline \multicolumn{3}{|l|}{ Winter season } \\
\hline Zygomycotina & 4 genera ( 6 species) $(26$ colonies $)$ & 4 genera (6 species) ( 26 colonies) \\
\hline Basidiomycotina & 2 genera ( 2 species) ( 5 colonies) & 2 genera( 2 species) ( 5 colonies $)$ \\
\hline Ascomycotina & 3 genera ( 3 species) ( 21 colonies) & 8 genera ( 8 species) (101 colonies) \\
\hline Anamorphic fungi & 15 genera ( 47 species) $(603$ colonies $)$ & 15 genera ( 47 species) $(786$ colonies $)$ \\
\hline Mycelia sterilia & 1 genus ( 2 species) (16 colonies) & 1 genus (2 species) (17 colonies) \\
\hline \multicolumn{3}{|l|}{ Summer season } \\
\hline Zygomycotina & 2 genera (4 species) (16 colonies) & 2 genera ( 4 species) (14 colonies) \\
\hline Basidiomycotina & - & - \\
\hline Ascomycotina & - & 1 genus ( 1 species) ( 6 colonies) \\
\hline Anamorphic fungi & 10 genera (33 species) (380 colonies) & 10 genera ( 34 species) (390 colonies) \\
\hline Mycelia sterilia & 1 genus ( 2 species) (19 colonies) & 1 genus(2species) (21 colonies) \\
\hline
\end{tabular}

Table 2: Comparative study of factors responsible for ACC Jamul factory area and Non Polluted area of Jamul

\begin{tabular}{|c|c|c|}
\hline & ACC Jamul factory area & Non Polluted area \\
\hline Rainy season & Average & Average \\
\hline Rainfall & $8.8 \mathrm{~mm}$ & $8.8 \mathrm{~mm}$ \\
\hline Temperature & $31.71^{\circ} \mathrm{C}$ & $31.62^{\circ} \mathrm{C}$ \\
\hline Humidity & $92 \%$ & High \\
\hline Organic matter & High & Average \\
\hline Winter season & Average & $3.3 \mathrm{~mm}$ \\
\hline Rainfall & $3.3 \mathrm{~mm}$ & $32.2^{\circ} \mathrm{C}$ \\
\hline Temperature & $32.2^{\circ} \mathrm{C}$ & $89.75 \%$ \\
\hline Humidity & $86.72 \%$ & High \\
\hline Organic matter & High & Average \\
\hline Summer season & Average & $1 \mathrm{~mm}$ \\
\hline Rainfall & $1 \mathrm{~mm}$ & $40.3^{\circ} \mathrm{C}$ \\
\hline Temperature & $40.3^{\circ} \mathrm{C}$ & $62.65 \%$ \\
\hline Humidity & $40.65^{\circ} \%$ & Low \\
\hline Organic matter & Low & \\
\hline
\end{tabular}




\section{Statistical analysis}

Statistical analysis of all test was carried out using ANOVA and t Test. Analysis were carried out for data of ACC Jamul and Nonpolluted area of Jamul using $t$ Test. Result obtained was not significant since there was not much difference between the fungal population of both area. This type of statistical analysis was done by Chakraborty ${ }^{6}$.

Table 3: t-Test

\begin{tabular}{|c|c|c|}
\hline \multicolumn{3}{|c|}{ t-Test: Two-Sample Assuming Unequal Variances } \\
\hline Mean & 20.16176471 & 21.90909091 \\
\hline Variance & 1470.794337 & 2582.110048 \\
\hline Observations & 68 & 77 \\
\hline Hypothesized Mean Difference & 0 & \\
\hline Df & 140 & \\
\hline t Stat & -0.235260581 & \\
\hline P(T<=t) one-tail & 0.40717513 & \\
\hline t Critical one-tail & 1.655810511 & \\
\hline $\mathrm{P}(\mathrm{T}<=\mathrm{t})$ two-tail & 0.814350261 & \\
\hline t Critical two-tail & 1.977053689 & \\
\hline
\end{tabular}

Table 4: Statistical difference between ACC and Non polluted area

\begin{tabular}{|c|c|c|c|c|}
\hline S.No & ACC Factory Area & & Non polluted area Jamul & \\
\hline 1 & Mean & 20.16176471 & Mean & 21.90909091 \\
\hline 2 & Standard Error & 4.650734188 & Standard Error & 5.790845942 \\
\hline 3 & Median & 8 & Median & 8 \\
\hline 4 & Mode & 2 & Mode & 8 \\
\hline 5 & Standard Deviation & 38.35093659 & Standard Deviation & 50.81446691 \\
\hline 6 & Sample Variance & 1470.794337 & Sample Variance & 2582.110048 \\
\hline 7 & Kurtosis & 23.78647828 & Kurtosis & 44.22213984 \\
\hline 8 & Skewness & 4.607937429 & Skewness & 6.261931497 \\
\hline 9 & Range & 248 & Range & 403 \\
\hline 10 & Minimum & 1 & Minimum & 1 \\
\hline 11 & Maximum & 249 & Maximum & 404 \\
\hline 12 & Sum & 1371 & Sum & 1687 \\
\hline 13 & Count & 68 & Count & 77 \\
\hline
\end{tabular}

Table 5: Standard deviation of samples

\begin{tabular}{|c|c|}
\hline ACC Factory Area & Non Polluted Area Jamul \\
\hline Standard Deviation & Standard Deviation \\
38.35093659 & 50.81446691 \\
\hline
\end{tabular}

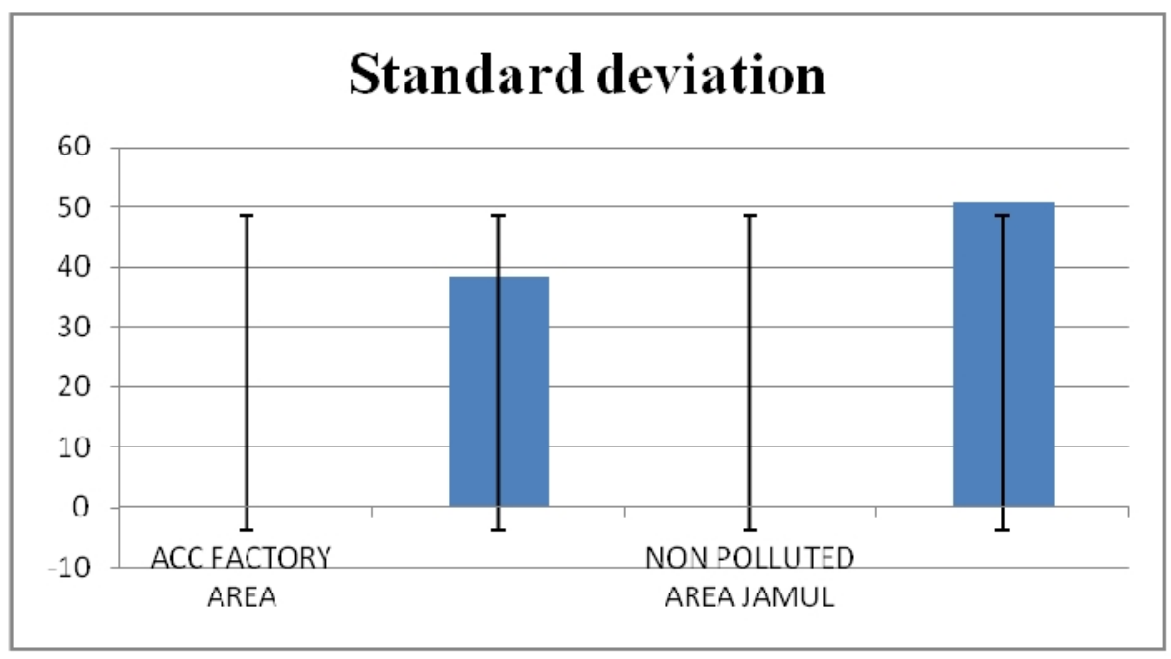

Figure 1: Standard Deviation of ACC factory and nonpolluted area Jamul

Table 6: Standard error of samples

\begin{tabular}{|c|c|}
\hline ACC Factory Area & Non Polluted Area Jamul \\
\hline Standard Error & Standard Error \\
4.650734188 & 5.790845942 \\
\hline
\end{tabular}




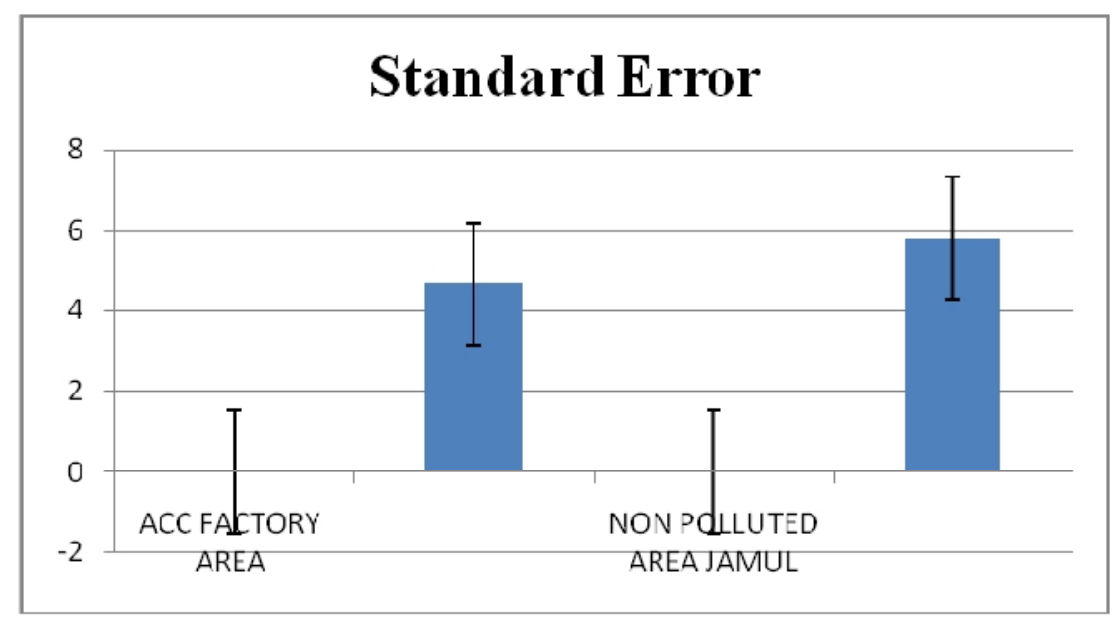

Figure 2: Standard Error of ACC factory and Nonpolluted area of Jamul

\section{ANOVA TEST}

Analysis of variance (ANOVA) was analysed for seasonal variation (Fungal colonies, fungal genera and fungal species of both the area with ANOVA at $\mathrm{P} \leq 0.05$ level (Significance Level) All test were conducted in 5 plates. The result obtained was significant it shows that there is effect of seasonal variation in both the areas. This type of statistical analysis was done by Mandloi ${ }^{7}$, Uddin ${ }^{8}$ aeromycoflora in jute fields Pavan and Manjunath ${ }^{9}$ in indoor and outdoor air quality of Poultry farm of Banglore. Inamdar ${ }^{10}$ studied antifungal activity of Hinguliya Manikyarasa in Candida albicans by its various concentration.

Table 7: Two way ANOVA for Grand Total Number of Fungal Colonies of ACC Jamul and Non polluted area Jamul

\begin{tabular}{|c|c|c|}
\hline Season & ACC & Non Polluted \\
\hline Rainy & 285 & 321 \\
\hline Winter & 671 & 935 \\
\hline Summer & 415 & 431 \\
\hline
\end{tabular}

Table 8: Two Factor without replication

\begin{tabular}{|c|c|c|c|c|c|c|}
\hline \multicolumn{7}{|c|}{ Anova: Two-Factor Without Replication } \\
\hline SUMMARY & Count & Sum & Average & Variance & & \\
\hline Rainy & 2 & 92 & 46 & 18 & & \\
\hline winter & 2 & 125 & 62.5 & 12.5 & & \\
\hline summer & 2 & 80 & 40 & 2 & & \\
\hline $\mathrm{ACC}$ & 3 & 142 & 47.33333 & 124.3333 & & \\
\hline Non polluted & 3 & 155 & 51.66667 & 149.3333 & & \\
\hline ANOVA & & & & & & \\
\hline Source of Variation & SS & $\mathrm{df}$ & MS & $\mathrm{F}$ & P-value & F crit \\
\hline Rows & 543 & 2 & 271.5 & 125.3077 & 0.007917 & 19 \\
\hline Columns & 28.16667 & 1 & 28.16667 & 13 & 0.069051 & 18.51282 \\
\hline Error & 4.333333 & $\overline{2}$ & 2.166667 & & & \\
\hline Total & 575.5 & 5 & & & & \\
\hline
\end{tabular}

Table 9: Two way ANOVA for Grand total number of fungal species of ACC Jamul and Non Polluted area of Jamul

\begin{tabular}{|c|c|c|}
\hline Season & ACC & Non Polluted \\
\hline Rainy & 43 & 49 \\
\hline Winter & 60 & 65 \\
\hline Summer & 39 & 41 \\
\hline
\end{tabular}

Table 10: Two way ANOVA for Grand total number of fungal genera of ACC Jamul area and Non polluted area

\begin{tabular}{|c|c|c|}
\hline Season & Acc & Non \\
\hline Rainy & 15 & 16 \\
\hline Winter & 25 & 30 \\
\hline Summer & 13 & 14 \\
\hline
\end{tabular}


Table 11: ANOVA method

\begin{tabular}{|c|c|c|c|c|c|c|}
\hline \multicolumn{2}{|c|}{ ANOVA: Two-Factor Without Replication } & & & \\
\hline SUMMARY & Count & Sum & Average & Variance & & \\
\hline rainy & 2 & 31 & 15.5 & 0.5 & & \\
\hline winter & 2 & 55 & 27.5 & 12.5 & & \\
\hline summer & 2 & 27 & 13.5 & 0.5 & & \\
\hline ACC & 3 & 53 & 17.66667 & 41.33333 & & \\
\hline Non polluted & 3 & 60 & 20 & 76 & & F crit \\
\hline ANOVA & & & & & & 19 \\
\hline Source of Variation & SS & df & MS & F & P-value & \\
\hline Rows & 229.3333 & 2 & 114.6667 & 43 & 0.022727 & 18.51282 \\
\hline Columns & 8.166667 & 1 & 8.166667 & 3.0625 & 0.222222 & \\
\hline Error & 5.333333 & 2 & 2.666667 & & & \\
\hline Total & 242.8333 & 5 & & & & \\
\hline
\end{tabular}

\section{CONCLUSION}

Fungal spores are common in our atmosphere and it is found in the factory area throughout the year. Fungi require certain environmental conditions and a suitable host for their growth and reproduction. Microorganisms can enter from outside area of factory through air and contaminate the atmosphere. Employees and visitors are also the sources of dust as they play role of dust carrier, breathing, cough and sneezing causes a dispersion of the microflora which can be present in human throat, pharynx and even lungs. Cement dust is also one of the major cause of respiratortary disorders. Different types of fungal spores were found in the air of factory area during investigation period. Spore and vegetative cell concentration does not decrease in the environment but regularly multiplies and increase. Soil, water and plants are the three main sources of aeromycoflora present in our environment. Vegetative cells and fungal spores present in the atmosphere emerge from soil, human activities like transportation, visiting, farming aerosols leads to the formation of fine droplets librated in the atmosphere. The soil is single unit which get associated with other particles by the action of wind. The present study serves a preliminary information on different groups of fungi that are present in the factory atmosphere .The regular monitoring of fungal spores may provide better knowledge of specific groups of fungi causing various types of health disorder which are human pathogenic. Therefore, it is very important to check and do regular air monitoring of aeromycoflora of factory area

Control of microorganisms in the ACC Jamul can be done by maintaining humidity and temperature in environment. The gases used for fumigation can also be used to control the growth of fungal species. In factory area cleanliness should be maintained by avoiding the accumulation of organic substances. The chemicals may be used for checking the multiplication of aeromycoflora .The windows and different ventilators ought to be sieved so as to minimize entry of microorganisms .ACC Factory area is a place where number of human being come everyday. The air of ACC factory area consist microorganisms which are harmful for human being. Therefore it is necessary to survey the aeromycoflora of ACC Factory area.

\section{REFERENCES}

1. Lacey, J.and Lacey,M.E. Microorganism in the air of cotton mills Ann.Occup.Hyg. 1987;31:10-19.

2. Seema Verma, Dr. Arunima Karkun ,Dr Kalpana Patle and Dr. Deepak Karkun. A Diversity of Fungal forms Present in Industrial Area of ACC Jamul., International Journal of scientific research and management, 2014;2(7): 1112-1117.

3. Jadhav S.K and Tiwari K.L. Aeromycoflora of Ravan village- Indian bot. Repotr 1994; (1):33-36.

4. Shrivastava Ranjana, Mahobia Deepika \& Meshram Nishant. Mycoflora Associated with soybean seeds. Life science Bulletein, 2009;6 (2):163-165.

5. Karkun Arunima, Tiwari K.L. and Jadhav S.K. Fungal diversity of Mandeepkhol cave in Chhattisgarh, India. Advances in bioresearch 2012;3(2): 119- 123.

6. Chakraborty Pampa, Gupta Bhattacharya Swati and Chanda Sunirmal. Aeromycoflora of an agricultural farm in West Bengal, India: A five-year study (1994 - 1999) Grana 2003;42: 248-254,

7. Mandloi Shikha, Srinivasa Rajashree, Mishra Renu Varma Ranjana (2013) Antifungal Activity of Alcoholic Leaf Extracts of Terminalia Catappa and Terminalia Arjuna on Some Pathogenic and Allergenic Fungi .Advances in Life Science and Technology $\mathrm{Vol} 8$

8. Uddin Naim. Estimation of aeromycoflora in jute fields. Aerobiologia 2005;21:75-80 .

9. Pavan R. and Manjunath K.Indoor and outdoor air quality of poultary farm at Banglore Int J Pharm Bio Sci 2014;Oct; 5(4): (B) $654-665$.

10. Inamdar Mahesh Prabhakar, Patil Ragini Rajan, Mhaske Rajesh Harishchandra, Singh Satyendra Rajendra Prasad. Study of antifungal activity of Hinguliya manikyarasa in Candida albicans by its various concentrations. Int. J. Res. Ayurveda Pharm. 2013;4(4):570-573 http://dx.doi.org/ $10.7897 / 2277-4343.04424$

\section{Cite this article as:}

Seema Verma and Arunima Karkun. Statistical analysis of Aeromycoflora of ACC Jamul factory area and non polluted area in Jamul, Bhilai, Dist Durg, Chhattisgarh, India. Int. J. Res. Ayurveda Pharm. May - Jun 2016;7(3):70-74 http://dx.doi.org/ $10.7897 / 2277-4343.073115$ every effort has been taken to verify the accuracy of the content published in our Journal. IJRAP cannot accept any responsibility or liability for the site content and articles published. The views expressed in articles by our contributing authors are not necessarily those of IJRAP editor or editorial board members. 